\title{
NORMATYWNY WYMIAR BRYTYJSKIEJ KONSTYTUCJI
}

W 1791 r. Thomas Paine ogłaszał, że Anglia nie ma konstytucji, ponieważ jeżeli nie może ona ,,przybrać widocznej formy”, nie istnieje. Konstytucja jest bowiem ,zbiorem składników (body of elements), do których możesz się odwołać i cytować artykuł po artykule; i który zawiera zasady, na jakich ustanowiony ma być rząd, sposób, w jaki winien on być zorganizowany, uprawnienia, jakie winien mieć, metodę wyborów, czas trwania parlamentów [...]; uprawnienia jakie winna mieć władza wykonawcza; - in fine - wszystko to co związane jest z pełną organizacją rządu (civil government) oraz zasady, na jakich winien on działać i jakimi winien być związany" ". Tak zdefiniowanej konstytucji Anglia rzeczywiście nie posiadała.

Łacińska etymologia słowa konstytucja jest powszechnie znana. W języku angielskim, w którym zostało ono z obszaru prawa cywilnego i kanonicznego wprowadzone w przestrzeń polityki, miało ono zawsze - a ma także i dziś znacznie szersze odniesienia aniżeli jedynie prawno-ustrojowe. W takim znaczeniu angielskie słowo constitution tradycyjnie (jeszcze przynajmniej do końca XVIII w.) miało wyłącznie deskryptywny charakter. Odpowiadało więc, najogólniej rzecz biorąc, pojęciu ustroju lub też formy rządu (frame of government) i służyło opisowi tego, wedle jakich reguł - to znaczy przez jakie instytucje oraz w jaki sposób - sprawowana była władza w określonej strukturze politycznej. Służyło więc do opisywania systemu rządów w państwie, obejmując instytucje władzy i zachodzące pomiędzy nimi relacje. Takie rozumienie słowa konstytucja zostało ostatecznie zakwestionowane w okresie rewolucji amerykańskiej² ${ }^{2}$ Odtąd miało ono oznaczać szczególny akt prawny będący wyrazem woli suwerennego ludu ustanawiającego dla siebie władzę i określającego właściwe formy jej sprawowania. Postać spisanego dokumentu, jaką przybrać miała rozumiana w ten sposób konstytucja, była więc jedynie rezultatem tak zdefiniowanego źródła prawowitej władzy państwowej ${ }^{3}$.

${ }^{1}$ T. Paine, Rights of Man, w: Thomas Paine. Collected Writings, New York 1955, s. 468 (wszystkie przekłady pochodza od autora artykułu).

${ }^{2}$ T. Fleiner wskazuje, że już w XVII w. konstytucja ,została proklamowana jako metoda ograniczania władzy rządu i implementacji zasady rządów prawa”. Zob. T. Fleiner, The Age of Constitutions, w: R. French, G. Lindell, Ch. Saunders (red.), Reflections on the Australian Constitution, Sydney 2003, s. 236. Ustawy angielskiego parlamentu, np. Magna Carta z 1215 r., Habeas Corpus Act z 1679 r. oraz Bill of Rights z 1689 r., ograniczały swobodę postępowania władz w stosunku do obywateli, nie miały one jednak charakteru praw podstawowych (fundamental laws). Parlament mógł wszak bez przeszkód zmienić ich przepisy bądź całkowicie uchylić. Eliminowały one absolutyzm władzy, ale nie jej arbitralność.

${ }^{3}$,Spisana konstytucja, dając głos zbiorowemu ludowi przemawiającemu jako suweren i określającemu formę rządów (government), była odmienna w teorii i praktyce od wcześniejszych konstytucji. 
Dla amerykańskich rewolucjonistów wyższa moc prawna konstytucji w stosunku do pozostałych aktów prawnych wynikała właśnie z tego, że była ona rezultatem woli suwerennego ludu ${ }^{4}$. Nadali oni więc słowu konstytucja nowe, jednoznacznie normatywne znaczenie, zmieniając w ten sposób jego sens. Konstytucja przestała być synonimem systemu rządów ${ }^{5}$. Zmiana nie nastapiła oczywiście z dnia na dzień. Nadawanie nowego znaczenia pojęciu konstytucji dokonywało się stopniowo, choć - trzeba przyznać - stosunkowo szybko. Tempo zmian napędzała bowiem konieczność znalezienia doktrynalnych podstaw do podważenia władzy imperialnego parlamentu nad amerykańskimi koloniami. Tych zaś mogło dostarczyć wyodrębnienie podstawowych zasad rządzenia, które służyłyby wyznaczeniu granic władzy instytucji ją sprawujących. W piśmiennictwie politycznym amerykańskich kolonii ten nowy sposób pojmowania konstytucji pojawił się pod koniec lat 60. XVIII w., ugruntowując się już w połowie kolejnej dekady ${ }^{6}$.

Normatywna koncepcja konstytucji, która narodziła się w okresie rewolucji oświeceniowych, oznacza początek współczesnego nam sposobu myślenia o konstytucjonalizmie jako zasadzie organizacji ustroju będącej przeciwieństwem rządów arbitralnych ${ }^{7}$. Rządy konstytucyjne można więc najogólniej zdefiniować jako sprawowanie władzy państwowej zgodnie $\mathrm{z}$ ustalonymi, powszechnie wiadomymi regułami, wiążącymi dla organów władzy, których to reguł one same nie wyznaczają i nie są władne dokonywać ich modyfikacji wedle własnego uznania. Tak właśnie cel konstytucji rozumieli Amerykanie. W zwięzły, a przy tym niezwykle trafny sposób, istotę zagadnienia ujął Thomas Jefferson, przekonując, że piastunów władzy państwowej należy „związać łańcuchami konstytucji"8. U źródeł konstytucjonalizmu leżało więc przekonanie, że „lekarstwem na nadużycie władzy nie mogło być ustanowienie jeszcze potężniejszej władzy lub też zastąpienie jednego piastuna arbitralnej władzy przez innego. Większa niekontrolowana władza stwarza większe

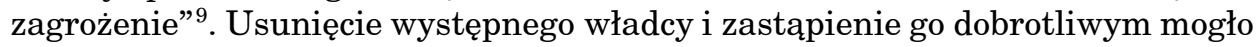
przynieść chwilową ulgę, ale nie mogło wyeliminować niebezpieczeństwa tyranii. Istota konstytucjonalizmu polega wobec tego na uznaniu, że ,,arbitralna władza może być poskromiona jedynie przez jej przeciwieństwo, nieobecność arbitralnej władzy lub obecność reguł (regularity)”. Nawet jeśli arbitralność nie może zostać $\mathrm{w}$ ten sposób całkowicie wyeliminowana, może być przynajmniej ograniczona ,supremacją ogólnych norm" ${ }^{10}$.

Amerykańskie konstytucje były spisanymi postanowieniami”. Ch. G. Fritz, American Sovereigns. The People and America's Constitutional Tradition before the Civil War, Cambridge 2009, s. 15.

${ }^{4}$ Por. T. Jefferson, Notes on the State of Virginia, w: Thomas Jefferson. Writings, New York 1984, s. 248-251.

${ }^{5}$ Zob. G. S. Wood, The Creation of the American Republic 1776-1787, Chapel Hill-London 1998, s. $267-268$.

${ }^{6}$ Zob. B. Bailyn, The Ideological Origins of the American Revolution, Cambridge-London 1992, s. $181-184$.

${ }^{7}$ Por. G. Casper, Changing Concepts of Constitutionalism: 18th to 20th Century, „,Supreme Court Review" 1989, s. 316.

${ }^{8}$ The Kentucky Resolutions of 1798. Resolutions Adopted by the Kentucky General Assembly, w: The Papers of Thomas Jefferson, t. 30: 1 January 1798 to 31 January 1799, Princeton-Oxford 2003, s. 554.

${ }^{9}$ S. Ratnapala, The Idea of a Constitution and Why Constitutions Matter, „Policy” 15, 1999-2000, s. 6.

${ }^{10}$ Ibidem. 
Dość klarowne rozumienie słowa konstytucja, jakie pojawiło się w okresie rewolucji oświeceniowych, zostało nieco rozmyte już w pierwszej połowie XIX w. wraz $\mathrm{z}$ pojawieniem się konstytucji oktrojowanych. Celem tego rodzaju dokumentów pozostawało nadal ograniczanie władzy (w tym sensie realizowały one zasadniczy postulat konstytucjonalizmu i różniły się od znanych już wcześniej w koloniach amerykańskich kart królewskich), ale ponieważ były nadawane przez samych rządzących, nie odpowiadały w pełni oświeceniowej definicji konstytucji. Tak więc już w pierwszej połowie XIX w. pojęcie konstytucji zatraciło znaczenie, jakie zostało mu nadane u schyłku poprzedniego stulecia. Oprócz konstytucji oktrojowanych, z czasem pojawiły się też konstytucje fikcyjne, które nawet jeśli formalnie ustanawiane były przez zbiorowego suwerena (co przecież nie zawsze miało miejsce), nie realizowały kluczowego postulatu konstytucjonalizmu, to znaczy nie służyły powściągnięciu arbitralności władzy. W rezultacie upowszechniania się aktów konstytucyjnych przyjmowanych w warunkach coraz bardziej odmiennych kultur politycznych i prawnych - stawały się one po prostu jednym z formalnych atrybutów państwa, niezależnie, w jaki sposób było ono rządzone. Konstytucja nabierała więc $\mathrm{w}$ coraz większym stopniu charakteru statutu organizacyjnego państwa. W ten sposób zatracała ona jednak swój pierwotny cel. Oczywiście konstytucjonaliści doby oświecenia doceniali również taka właśnie organizatorska funkcję konstytucji, niemniej jednak - jak się wydaje - postrzegali ją zawsze przez pryzmat jej telos, które miało znaczenie podstawowe. W każdym razie proces, o którym mowa, niewątpliwie ułatwił ponowne utożsamienie słowa constitution $\mathrm{z}$ systemem rządów, ze sposobem zorganizowania władzy państwowej.

Wielu badaczy skłonnych jest $\mathrm{w}$ związku $\mathrm{z}$ tym początków konstytucjonalizmu - rozumianego jako synonim rządów konstytucyjnych - szukać znacznie wcześniej aniżeli w ,,epoce światła”, już nie tylko w średniowieczu, ale nawet i w starożytności ${ }^{11}$. W takim ujęciu rewolucje oświeceniowe wyznaczają jedynie kolejny etap w rozwoju idei konstytucjonalizmu, jeśli ważny lub ważniejszy od wcześniejszych, to tylko dlatego, że to właśnie wówczas „koncepcja fundamentalnego prawa pisanego" uzyskała szczególne znaczenie ${ }^{12}$. Przyjęcie tego rodzaju perspektywy pozwala nadać pojęciu constitution szersze znaczenie, również deskryptywne, a więc niejako ponownie utożsamić je nie tylko z instrumentem służącym ograniczeniu władzy państwowej i wyeliminowaniu jej arbitralności, ale w ogóle $\mathrm{z}$ systemem rządów takim, jakim jest on $\mathrm{w}$ rzeczywistości, a więc $\mathrm{z}$ określonym sposobem zorganizowania państwa i sprawowania władzy państwowej ${ }^{13}$. W ten sposób konstytucjonalizm przestaje być przeciwieństwem rządów arbitralnych, a staje się synonimem jakichkolwiek rządów. Określenie „rządy konstytucyjne” (constitutional government) nabiera cech tautologii skoro $\mathrm{w}$ takim ujęciu każde rządy muszą być $\mathrm{z}$ definicji konstytucyjnymi. Zwolennicy tego rodzaju poglądów na poparcie swego stanowiska przywołują przykłady historycznego używania łacińskiego terminu

${ }^{11}$ Zob. np. M. G. M. Cabra, El Concepto de Constitución, „Anuario de Derecho Constitucional Latinoamericano" 2005, s. 14 i n.

12 Ibidem, s. 22.

${ }^{13}$ Por. G. Maddox, A Note on the Meaning of 'Constitution', „American Political Science Review” 76, 1982 , nr 4, s. 808. 
constitutio $\mathrm{w}$ takim właśnie znaczeniu, to jest na określenie formy organizacji i sposobu sprawowania władzy, sięgając w tym celu do pism Cycerona, a nawet Arystotelesa.

Utożsamianie konstytucjonalizmu i rządów konstytucyjnych z dowolną formą organizacji wspólnoty politycznej i sprawowanej w jej ramach władzy nie bierze jednak pod uwagę zasadniczej zmiany w sposobie myślenia o tych -jakże kluczowych - zagadnieniach, jaka dokonała się w okresie oświecenia, odzwierciedlonej w piśmiennictwie politycznym epoki. Jeśli wszelkie rządy są konstytucyjne, ponieważ sprawowane są wedle jakichś reguł - niezależnie jakiej rangi i w jaki sposób i przez kogo ustanawianych - alternatywą wobec nich pozostawać może jedynie anarchia. W każdej wspólnocie politycznej władza musi być w jakiś sposób zorganizowana. Jest to wszak konieczny warunek jej elementarnej skuteczności. Rządy konstytucyjne tym różnią się od innych form sprawowania władzy, że ich celem jest jej ograniczanie, a precyzyjnie rzecz ujmując: wyeliminowanie jej arbitralności. Konstytucjonalizm stara się osiagnąc ten cel poprzez ustanowienie norm wiążących dla osób zaangażowanych w sprawowanie władzy.

O konstytucjonalizmie jako fundamentalnej zasadzie organizacyjnej ustroju państwa można mówić, począwszy od XVIII w. Wcześniej konstytucjonalizm oznaczał zaledwie dążenie do związania piastunów władzy wyższym, krępującym ich wolę prawem. Miał wartość postulatywną. Dopiero w epoce oświecenia zamiast rozmaicie uzasadnianego prawa do oporu wobec władcy lub zgoła do rewolucji pojawiło się odwołanie do norm ustanawianych przez „lud”, „,naród” lub jakkolwiek inaczej nazywaną polityczną zbiorowość, regulujących postępowanie rządzących, których to norm nie mogli oni samodzielnie zmieniać ani znosić. Odnajdywane w myśli politycznej rozmaitych epok postulaty podnoszące konieczność ograniczenie rządzących „,wyższym prawem”, normami istniejącymi niezależnie od ich woli, których nie mogliby oni zmieniać, a które krępowałyby ich swobodę, właśnie w okresie rewolucji oświeceniowych znalazły przełożenie na język norm odpowiedzialnych za regulację stosunków władczych w państwie w dwóch zasadniczych wymiarach: w obrębie samych organów władzy oraz pomiędzy rządzącymi a rządzonymi.

Dla osiemnastowiecznych konstytucjonalistów było oczywiste, że wyeliminowanie arbitralności władzy można osiągnąć jedynie poprzez ustanowienie „wyższego prawa” (higher law) - ustawy zasadniczej - którego źródłem byłaby wola zbiorowego suwerena i które znajdowałoby się poza zasięgiem władzy ustawodawczej parlamentu. Już w 1758 r. szwajcarski pisarz polityczny Emerich de Vattel utożsamiał „,konstytucję państwa” (Constitution de l'Etat) z ,,podstawowymi prawami” (Loix fondamentales), których legislatorzy nie mogli zmienić bez upoważnienia ze strony „narodu” (nation) ${ }^{14}$. Normatywna koncepcja konstytucji podstawą rządów konstytucyjnych czyniła więc akt prawny. Konstytucja musiała być ustanowiona poprzez intencjonalne działanie zbiorowego podmiotu suwerenności, przybierając w ten sposób „widoczna formę", o której pisał T. Paine.

${ }^{14}$ E. de Vattel, Les droit des gens. Ou principes de la loi naturelle, appliqués à la conduite \& aux affaires des nations \& des souverains, Londres 1758, ks. I, rozdz. III, s. 36-37. 
Kiedy angielski historyk Edward A. Freeman w wydanej w 1872 r. pracy The Growth of the English Constitution posłużył się pojęciem „konwenansowej konstytucji" (conventional constitution) - traktowanym przezeń jako synonim konstytucji „niespisanej” (unwritten) - pojęcie konstytucji miało więc już powszechnie przyjęte znaczenie nadane mu przez rewolucje oświeceniowe. $\mathrm{Na}$ wyspach brytyjskich koncepcja konstytucji jako szczególnego rodzaju aktu prawnego nie znalazła oczywiście uznania. Dlatego też w Wielkiej Brytanii słowo constitution używane $\mathrm{w}$ kontekście ustrojowym nie utraciło swego pierwotnego, deskryptywnego znaczenia. Było ono więc wciąż synonimem systemu rządów. W takim - zdaje się - znaczeniu użył go w tytule swego opus magnum Walter Bagehot.

Lektura pracy Edwarda A. Freemana przekonuje jednak, że słowo konstytucja używane $\mathrm{w}$ kontekście politycznym nabrało $\mathrm{z}$ czasem również wartości normatywnej, i to mimo braku w Wielkiej Brytanii konstytucji w formie ustawy zasadniczej. Opisując funkcjonowanie brytyjskich instytucji ustrojowych Korony, parlamentu i ministrów tworzących gabinet - oraz ich wzajemne relacje, zwraca on bowiem uwagę na to, że regulowane są one nie tylko przez normy prawne. Urzędnik Korony (officer of the Crown) pełniący urząd powierzony mu przez Koronę, lekceważąc negatywne dla niego głosowania $\mathrm{w}$ obu izbach parlamentu (votes of censure) nie popadnie w konflikt z prawem. „Lecz człowiek postępujący w taki sposób, zostałby powszechnie uznany za depczącego jedną z najbardziej niewątpliwych zasad niespisanej, lecz powszechnie akceptowanej konstytucji”" ${ }^{15}$. Tak więc ,,szerokie granice niespisanej konstytucji”, przeciwko którym, jak pisał Edward A. Freeman, można było „,zgrzeszyć”, wyznaczały wymogi postępowania konstytucyjnego. „Politycy mogą debatować, czy takie czy inne zachowanie jest lub nie jest konstytucyjne, tak jak prawnicy moga debatować, czy takie zachowanie jest lub nie jest legalne. Lecz sama forma debaty wskazuje, że istnieje konstytucja, która winna być przestrzegana, tak jak w innym wypadku istnieje prawo, które winno być przestrzegane" ${ }^{16}$. Słowo konstytucja ma więc $\mathrm{w}$ tym kontekście niewątpliwie znaczenie normatywne. Edward A. Freeman przytacza szereg przykładów, w jaki sposób „niespisana konstytucja” (unwritten constitution) - tym pojęciem posługuje się najczęściej - ogranicza władzę Korony, uniemożliwia monarsze korzystanie $\mathrm{z}$ przysługujących mu uprawnień $\mathrm{w}$ zakresie powoływania i odwoływania ministrów lub sankcjonowania ustaw parlamentu według uznania, a więc krótko mówiąc, służy powściaganiu arbitralności władzy ${ }^{17}$. Owa „niespisana” bądź „konwenansowa” konstytucja ma zatem walor normatywny, skoro wyznacza standardy „,konstytucyjnego” postępowania i skoro można dopuścić się jej naruszenia, jej „obrazy” (offence against the Constitution). Edward A. Freeman zauważył też pojawienie się „bardziej wyrafinowanej doktryny”, wedle której „moga istnieć przekroczenia konstytucji, które nie sa przekroczeniami prawa" ${ }^{18}$. Normatywna konstytucja nie musiała być zatem zbiorem norm prawnych.

\footnotetext{
${ }^{15}$ E. A. Freeman, The Growth of the English Constitution, London 1876, s. 117.

${ }^{16}$ Ibidem.

${ }^{17}$ Ibidem, s. 118-119.

${ }^{18}$ Ibidem, s. 113.
} 
Edward A. Freeman nie był prekursorem postrzegania brytyjskiej konstytucji w ten, odmienny od dominującego jeszcze w XVIII w., sposób. Równo cztery dekady przed publikacją książki angielskiego historyka w podobnym tonie o konstytucji pisał John Austin, który posługiwał się już pojęciem „niekonstytucyjny” (unconstitutional). Nazywając je „epitetem”, rozróżniał przy tym jego wąskie i szerokie odniesienie. W wąskim znaczeniu określać miało ono zachowanie sprzeczne z prawem konstytucyjnym, w szerszym używane było do „maksym, których Suweren zwykle przestrzega, a do których przeważająca część społeczeństwa lub też przeważająca część jego wpływowych członków odnosi się z uczuciem aprobaty". Maksymy te moga być przyjmowane przez samego Suwerena bądź państwo, częściej jednak ,są im po prostu narzucane przez poglądy przeważające we wspólnocie". Tak czy inaczej są one dla nich - to jest dla Suwerena lub państwa - wiążące, nawet jeśli ich sankcja jest „tylko moralna". W ten sposób jakikolwiek akt monarchy bądź innego organu sprzeczny z owymi maksymami może być - według Johna Austina - nazwany niekonstytucyjnym ${ }^{19}$. W tym kontekście oznacza to, że akt ów ,jest niezgodny z jakąś określoną zasadą lub maksymą: iż określona najwyższa władza (supreme government) wyraźnie przyjęła taka zasadę lub przynajmniej zwykle jej przestrzegała: że przeważająca część społeczeństwa lub też przeważająca część jego wpływowych członków odnosi się do zasady z uznaniem: i że skoro najwyższa władza zwykle przestrzegała zasady i skoro przeważająca część społeczności odnosi się do niej z uznaniem, akt, o którym mowa, musi być sprzeczny z oczekiwaniami tych ostatnich oraz musi powodować ich oburzenie (must schock their opinions and sentiments)" ${ }^{20}$. John Austin wyraźnie więc rozdzielał już bezprawność jakiegoś postępowania od jego niekonstytucyjności. To, że pewne zachowanie było niekonstytucyjne (unconstitutional), nie oznaczało równocześnie, iż było ono bezprawne (illegal). Innymi słowy, działanie organów władzy mogło być równocześnie zgodne z prawem i niezgodne z konstytucja. Te dwa pojęcia - bezprawności i niekonstytucyjności - jeszcze w $1788 \mathrm{r}$. William Paley traktował jako synonimy, podkreślając z naciskiem, że „pojęcia konstytucyjny i niekonstytucyjny oznaczaja zgodny z prawem (legal) i bezprawny (illegal)". William Paley - zdaniem Gordona S. Wooda sumujacy dorobek osiemnastowiecznej myśli angielskiej w tym zakresie ${ }^{21}$ - definiował konstytucje jako ,jeden szczególny rozdział, sekcję, lub tytuł kodeksu praw publicznych; różny od pozostałych jedynie wyższym znaczeniem przedmiotu, którego tyczy”. Oznaczało to, że „,ustawa parlamentu nigdy nie może niekonstytucyjna w ścisłym i właściwym użyciu tego pojęcia”22. Jej „niekonstytucyjność" polegać mogła jedynie na tym, że była ona sprzeczna z wcześniejsza ustawą parlamentu, w ten sposób ją zastępując.

Trudno precyzyjnie określić, kiedy tego rodzaju tradycyjne i powszechne jeszcze w XVIII w. rozumienie brytyjskiej konstytucji zaczęło być kwestionowane. W każdym razie dziewiętnastowieczni badacze brytyjskiego ustroju

\footnotetext{
${ }^{19}$ J. Austin, The Province of Jurisprudence Determined, Albemarle Street, London 1832, s. 272.

${ }^{20}$ Ibidem, s. 273.

${ }^{21}$ G. S. Wood, op. cit., s. 261.

${ }^{22}$ W. Paley, The Principles of Moral and Political Philosophy, Indianapolis 2002, s. 326-327.
} 
opisywali już takie instytucje, jak gabinet, które funkcjonowały w obszarze władzy państwowej mimo braku jakiejkolwiek podstawy prawnej. Byli oni też świadomi ograniczeń królewskich prerogatyw, które nie wynikały ani z norm prawa stanowionego, ani powszechnego. Dostrzegali już zatem, że ustrój brytyjski regulowały nie tylko przepisy prawa, ale i normy o charakterze pozaprawnym ${ }^{23}$, które Albert V. Dicey - podążając tropem E. A. Freemana nazwał konwenansami konstytucyjnymi (constitutional conventions).

Już John S. Mill na początku lat 60. XIX w. wskazywał, że konwenanse dopóty moga obowiązywać, dopóki zapewniać będą ,,panowanie” tej z władz, która rzeczywiście „ma przewagę”, to znaczy stanowi realną siłę polityczna.. „Tą [zaś] w Anglii jest władza ludu" ${ }^{24}$. Uznanie zasady suwerenności parlamentu musiało wykluczać możliwość umieszczenia suwerenności ludu w katalogu zasad konstytucyjnych Zjednoczonego Królestwa. Albert V. Dicey, największy adwokat zasady suwerenności parlamentu, rozwiązał ten oczywisty dylemat, wskazując na parlament jako suwerena prawnego, a na „naród” bądź częściej ogół lub większość wyborców (electorate) jako suwerena politycznego. Suwerenność narodu realizować się miała poprzez parlament, który jako prawny suweren dysponował pełnią władzy legislacyjnej, to znaczy - jak pisał Albert V. Dicey, cytując Josepha L. De Lolme'a - mógł zrobić wszystko poza zamianą kobiety w mężczyznę. Jaka wobec tego w tak ukształtowanym schemacie była rola konwenansów konstytucyjnych? To właśnie dzięki nieformalnym normom konstytucyjnym wola politycznego suwerena miała w praktyce uzyskiwać decydujące znaczenie. Forsując koncepcję suwerenności parlamentu, Albert V. Dicey przyznawał równocześnie, że to ,,wyborcy są w rzeczywistości (in fact) suwerenem Anglii" ${ }^{25}$. Parlament był suwerenny w tym sensie, że jego władza nie była w żaden sposób skrępowana pod względem prawnym. W odróżnieniu na przykład od Stanów Zjednoczonych żaden zewnętrzny wobec parlamentu organ w postaci Sądu Najwyższego nie mógł powściagać jego władzy. Owa suwerenność znajdowała jednak ograniczenia wynikające $\mathrm{z}$ obowiązywania konwenansów konstytucyjnych. Albert V. Dicey wskazywał, że wszystkie normy konwenansowe miały wspólny cel. Było nim ,zapewnianie, by parlament lub gabinet, który jest pośrednio powoływany przez parlament, uskuteczniał w ogólnym rozrachunku wolę tej siły, która we współczesnej Anglii jest prawdziwym politycznym suwerenem w państwie - większości wyborców lub (by użyć popularnego, choć nie całkiem właściwego określenia) narodu" ${ }^{26}$. Albert V. Dicey nigdy wprost nie pisał o suwerenności ludu jako zasadzie brytyjskiego ustroju. Jego słowa nie pozostawiająjednak wątpliwości co do tego, że miał on pełną świadomość roli, jaką odgrywają konwenanse, a która polegała na torowaniu drogi tej właśnie zasadzie, skoro uważał, że sens obowiązywania konwenansowych norm konstytucyjnych polega na zabezpieczaniu supremacji Izby Gmin, a ostatecznie, poprzez obieralną izbę parlamentu, supremacji narodu. „Nasz współczesny kodeks moralności konstytucyjnej zapewnia, choć

${ }^{23}$ Zob. O. Hood Philips, Constitutional Conventions: Dicey's Predecessors, ,Modern Law Review” 26, 1966, nr 2, s. 137-144.

24 J. S. Mill, Considerations on Representative Government, New York 1862, s. 99.

${ }_{25}$ A. V. Dicey, Introduction to the Study of the Law of the Constitution, London 1915, s. 425-426.

${ }^{26}$ Ibidem, s. 424. 
okrężną drogą, to co gdzie indziej nazywa się suwerennością ludu"27. Tego rodzaju sformułowania nie zawieraja najmniejszej dwuznaczności.

Cel, który w innych państwach próbowano zrealizować, ustanawiając formalne akty konstytucyjne, został w Wielkiej Brytanii - a później i w państwach powstających $\mathrm{w}$ obrębie brytyjskiego imperium kolonialnego oraz w rezultacie jego rozpadu - osiągnięty w inny sposób. Wielka Brytania ma więc współcześnie konstytucję w znaczeniu normatywnym (miała ja już z cała pewnością w drugiej połowie XIX w.) ponieważ ustrój tego państwa oparty jest na normach wyższego rzędu, determinujących sposób wykonywania władzy państwowej i znajdujących się poza zasięgiem tych, których zachowanie regulują, a więc najogólniej rzecz biorąc: organów tej władzy. Konwenanse konstytucyjne stały się normami eliminującymi arbitralność władzy nie tylko dlatego, że determinowały relacje pomiędzy egzekutywa a parlamentem, ale również - a być może nawet przede wszystkim - ze względu na to, że wprowadzając do brytyjskiego ustroju zasadę suwerenności ludu, nałożyły na władzę ustawodawcza parlamentu konstytucyjne ograniczenia.

Zasada suwerenności parlamentu, której geneza sięga Chwalebnej Rewolucji (Glorious Revolution) 1688 r., przetrwała w Wielkiej Brytanii ze względu na brak konstytucji w znaczeniu formalnym. Zapewniała ona parlamentowi warto pamiętać o jego trójczłonowej strukturze tworzonej przez króla, lordów i gminy - nie tylko pełnię władzy ustawodawczej, ale i prawodawczą omnipotencję, oznaczająca, że parlament stanowić mógł wszelkie prawa, jego ustawy nie mogły być skutecznie kwestionowane przed żadnym organem ani konfrontowane pod rygorem nieważności z jakimikolwiek normami wyższego rzędu. Jeszcze pod koniec XVIII w. przeważał pogląd, że ustawa parlamentu nie może być niekonstytucyjna. Jednak już w latach 30. XIX w. John Austin podnosił istnienie ,,zasad” i ,maksym”, które ograniczały władzę ustawodawcza parlamentu w ten sposób, że czyniły jego ustawy „niekonstytucyjnymi”. Te zasady i maksymy przerodziły się w normy konstytucyjne pełniące tę sama funkcję, jaka w innych państwach wypełniaja konstytucje w formie ustaw zasadniczych. Zasada suwerenności parlamentu została więc skutecznie ograniczona przez determinowaną rozwojem konwenansów konstytucyjnych zasadę suwerenności ludu. To właśnie ona już w XIX w. wyznaczała - niezależnie od dogmatyki prawniczej - realny zasięg władzy ustawodawczej parlamentu, która była legitymowana tylko wówczas, gdy jej wykonywanie znajdowało akceptację politycznego suwerena. Nadal to właśnie „zasada demokracji przedstawicielskiej funkcjonuje [...] jako podstawowe uzasadnienie władzy ustawodawczej dzierżonej przez parlament" ${ }^{28}$ w ustroju brytyjskim.

Współcześnie $\mathrm{z}$ coraz większym natężeniem pojawiają się $\mathrm{w}$ Wielkiej Brytanii próby poszukiwania prawnych - lub przynajmniej w części prawnych ograniczeń władzy. W tym kontekście wskazać należy trzy odrębne, choć w tym sensie powiązane ze sobą procesy.

${ }^{27}$ Ibidem, s. 426.

${ }^{28}$ M. Elliott, Parliamentary Sovereignty and the New Constitutional Order: Legislative Freedom, Political Reality and Convention, „Legal Studies” 22, 2002, nr 3, s. 368. 
Pierwszym jest powracająca co jakiś czas idea przyjęcia spisanej konstytucji. Postulaty tego rodzaju formułowane były przez przedstawicieli doktryny już przed wieloma laty ${ }^{29}$, jednak nie stanowiły one nigdy dominującego ,,sposobu myślenia brytyjskich konstytucjonalistów" ${ }^{30}$. Zwolennicy skodyfikowanej konstytucji nie należeli też do głównego nurtu w dwóch największych brytyjskich partiach politycznych. W rezultacie ustanowienie formalnej konstytucji Zjednoczonego Królestwa nie stało się częścią doktryny ustrojowej ani - co wydaje się zrozumiałe - Partii Konserwatywnej, ani Partii Pracy.

Nasilenie debaty nad przyjęciem ustawy zasadniczej przypadło na przełom lat 80. i 90. XX w. Pomiędzy 1990 a 1992 r. zaprezentowano aż trzy projekty konstytucji dla Zjednoczonego Królestwa ${ }^{31}$. W opublikowanej w 2007 r. Zielonej Księdze zatytułowanej Governance of Britain rząd Partii Pracy nawiązał do idei skodyfikowanej konstytucji, choć w bardzo ostrożny i nie całkiem jednoznaczny sposób $^{32}$. W każdym razie zapowiedź podjęcia działań zmierzających do ustanowienie konstytucji nie została tam wprost sformułowana. Znaczenie tego dokumentu polega jednak na tym, że zagadnienie konstytucji pisanej po raz pierwszy podniesione zostało $\mathrm{w}$ dokumencie rządowym ${ }^{33}$. Trudno oczywiście powiedzieć, w jakim stopniu realna jest perspektywa uchwalenia w Wielkiej Brytanii formalnej konstytucji. W każdym razie oznaczałoby to radykalna zmianę ustrojową dotycząca nie tylko formy norm konstytucyjnych, ale najpewniej też i ich treści. Nie wszystkie konwenanse można by bowiem przełożyć na język norm prawnych.

Przez pryzmat próby wprowadzenia do brytyjskiego porządku ustrojowego wyższych norm prawnych - i w ten sposób realizację postulatów konstytucjonalizmu na drodze prawnej, ale bez ustanowienie spisanej konstytucji - należy również postrzegać zmianę podejścia brytyjskich sądów do zasady domniemanej derogacji ustaw parlamentu oraz swoisty renesans tak zwanego konstytucjonalizmu prawa powszechnego (common law constitutionalism).

W orzeczeniu Komitetu Sądowego Izby Lordów z 2002 r. ${ }^{34}$ po raz pierwszy w orzecznictwie najważniejsze ustawy ustrojowe zostały zdefiniowane jako akty o szczególnym statusie prawnym ${ }^{35}$. Określone one zostały mianem ustawodawstwa konstytucyjnego (constitutional legislation) różnym od ustawodawstwa zwykłego (ordinary legislation). Zdaniem orzekajacych $\mathrm{w}$ sprawie członków Komitetu status ustaw konstytucyjnych posiadać mają te spośród ustaw parlamentu, w których: a) w ogólny sposób regulowane sa stosunki pomiędzy obywatelem a państwem; b) powiększany lub pomniejszany jest zakres ,,tego, co nazwalibyśmy dziś podstawowymi prawami konstytucyjnymi”

${ }^{29}$ Zob. O. Hood-Philips, Reform of the Constitution, London 1970, s. 144-161.

${ }^{30}$ A. Zięba, Wspótczesne brytyjskie doktryny polityczne, Białystok 2001, s. 198.

${ }^{31}$ Zob. M. Kruk, Nowe projekty brytyjskiej konstytucji pisanej, „Państwo i Prawo” 1993, z. 8, s. 70-78.

${ }^{32}$ Por. The Governance of Britain, Presented to Parliament by the Secretary of State for Justice and Lord Chancellor by Her Majesty Command, July 2007 CM 7170, s. 62, tekst opublikowany na: http://www.official-documents.gov.uk.

${ }^{33}$ Por. A. Le Sueur, Gordon Brown's New Constitutional Settlement, „Public Law” 2008, Spring, s. 21.

${ }^{34}$ Thoburn v. Sunderland City Council, [2002] EWHC 195 (Admin).

${ }^{35}$ P. Mikuli, Sady a parlament $w$ ustrojach Australii, Kanady i Nowej Zelandii (na tle rozwiazań brytyjskich), Kraków 2010, s. 36. 
(fundamental constitutional rights) ${ }^{36}$. Różnica pomiędzy ustawami zwykłymi a konstytucyjnymi polegać ma zaś na tym, że przepisy tych drugich nie moga być uchylane przez inne ustawy parlamentu w sposób dorozumiany ${ }^{37}$. Parlament nadal władny jest je zmieniać bez żadnych ograniczeń, tak jak wszystkie inne ustawy, ale może to czynić tylko wyraźnie i bezpośrednio. Stwierdzając, że przepisy niektórych ustaw - tych należących do kategorii ,ustawodawstwa konstytucyjnego" - nie moga podlegać dorozumianej derogacji, „Lordowie prawa właściwie powiedzieli parlamentowi, że sądy nie będą sankcjonować niektórych przejawów wykonywania przez parlament jego władzy ustawodawczej". Stąd tylko krok do odmowy stosowania przez sędziów ustaw parlamentu ${ }^{38}$. W obiter dictum do orzeczenia Komitetu Sądowego Izby Lordów z 2005 r. w sprawie Jackson v. Attorney General lord Steyn już wprost wskazał na istnienie „konstytucyjnych fundamentów”, których parlament nie może swym ustawodawstwem obalić, sugerując równocześnie, że ochrona owych fundamentów należeć winna do sądów ${ }^{39}$.

Poszukiwanie ,,wyższego prawa” - którym związany byłby nawet parlament - w normach prawa powszechnego ma w Wielkiej Brytanii bardzo długa tradycję. W tym kontekście przywołuje się przede wszystkim słynne wystąpienie sir Edwarda Coke'a w sprawie dr. Bonhama (Dr. Bonham's case) z 1610 r. Orzeczenie to wskazuje się jako zapowiedź sądowej kontroli konstytucyjności prawa (judicial review) pozwalającej sędziom odmawiać ważności ustawom uchwalonym wbrew normom wyższego rzędu odnajdywanym już jednak nie tyle - lub niekoniecznie - w common law, ile w spisanej konstytucji. Sir Edward Coke argumentował, że „w wielu wypadkach prawo powszechne kontroluje ustawy parlamentu i czasami winno rozstrzygać o ich nieważności (adjudge them to be void), jako że kiedy ustawa parlamentu przeciwna jest zdrowemu rozsądkowi i poczuciu słuszności (common right and reason) bądź [z nimi] sprzeczną, bądź niemożliwą do zastosowania, prawo powszechne będzie ją kontrolować i rozstrzygać o nieważności takiej ustawy". Powołując się - jak wykazali późniejsi badacze niezbyt wiernie - na wcześniejsze orzeczenia angielskich sądów, przekonywał też, że w sytuacji kiedy ustawa sprzeciwia się zasadom rozumu i sprawiedliwości, jej autorzy nie powinni dążyć do egzekucji jej przepisów ${ }^{40}$.

Amerykańskim rewolucjonistom sprawa dr. Bonhama służyła jako argument w walce $\mathrm{z}$ omnipotencja ustawodawczą parlamentu. Intencją sir Edwarda Coke’a nie było jednak zanegowanie suwerenności parlamentu, ale raczej wskazanie na konieczność interpretacji uchwalanych przezeń ustaw w zgodzie z uznanymi zasadami rozumu i sprawiedliwości, stanowiącymi podstawę

${ }^{36}$ Thoburn v. Sunderland City Council, § 62.

${ }^{37}$ Ibidem, $§ 63$.

${ }^{38}$ R. Prebble, Constitutional Statutes and Implied Repeal: The Thoburn Decision and the Consequences for New Zealand, ,Victoria University of Wellington Law Review” 36, 2005, nr 2, s. 299.

39 Jackson and others (Appellants) v. Her Majesty's Attorney General (Respondent), [2005] UKHL 56, $\S 102$.

${ }^{40}$ Dr. Bonham's Case (1610) Hilary Term, 7 James 1. Reports, t. 8, s. 118 a, cyt. za: The Selected Writings and Speeches of Sir Edward Coke, wyd. S. Sheppard, Indianapolis 2003, s. 264. 
wszelkiego prawa ${ }^{41}$. Gdy mówił o „rozstrzyganiu o nieważności ustaw”, nie chodziło mu o to, aby sędziowie wyznaczyli granice władzy ustawodawczej parlamentu, ale aby sądy interpretowały ustawy ściśle, jeśli byłoby to konieczne dla zapewnienia zgodności z owymi uznanymi zasadami. W takiej sytuacji sędziowie mogliby albo nie wziąć pod uwagę fragmentów ustawy w rozstrzyganej sprawie, albo uznać, że reguluje ona inną materię, a więc nie znajduje ona $\mathrm{w}$ danej sprawie zastosowania ${ }^{42}$.

Współcześnie zwolennicy konstytucjonalizmu common law, odwołując się do wystapienia słynnego siedemnastowiecznego jurysty, nie przyznaja więc sędziom prawa odmowy stosowania ustaw ze względu na ich niezgodność z normami prawa powszechnego. Nie przekonuja zatem o hierarchicznej wyższości common law w stosunku do prawa stanowionego przez parlament. Uważają jednak, że sędziowie dysponują ,nieodzowną, dyskrecjonalną władzą stwierdzania, kiedy parlament korzysta ze swej suwerennej władzy w »niekonstytucyjny sposób«; to znaczy, kiedy parlament stanowi prawo wbrew normom prawnym bądź podstawowym wytycznym (baselines) politycznego zachowania postrzeganym przez sądy jako mające szczególne znaczenie w ramach niespisanej brytyjskiej konstytucji" ${ }^{43}$. Tego rodzaju deklaracje niekonstytucyjności nie niosłyby ze sobą żadnych skutków prawnych, nie oznaczałyby odmowy zastosowania przez sąd ustawy uznanej przezeń za niekonstytucyjna, tym bardziej zaś by jej nie unieważniały. Deklaracja niekonstytucyjności miałaby jedynie uświadamiać politykom i opinii publicznej różnicę w postrzeganiu konstytucyjnych obowiązków parlamentu pomiędzy nim samym a sądami. Rozwiązanie sporu miałoby jednak nastąpić poprzez odwołanie się do mechanizmów demokratycznego procesu politycznego ${ }^{44}$.

Oświeceniowa definicja konstytucji trwale zaciążyła nad rozumieniem zarówno tego pojęcia, jak i pokrewnego mu terminu konstytucjonalizm, które zostały ściśle zespolone z konstytucją będąca ,„najwyższym prawem”, z ustawą zasadniczą, której istnienie w takim ujęciu stawało się warunkiem realizacji zasady lub też idei konstytucjonalizmu. Polskie piśmiennictwo naukowe nie pozostaje pod tym względem wyjątkiem ${ }^{45}$. Utożsamienie konstytucjonalizmu z eliminacją arbitralności władzy za pomoca norm prawnych wspólne jest zresztą zarówno tym badaczom, którzy konstytucjonalizm wiążą ściśle z konstytucja $\mathrm{w}$ formie ustawy zasadniczej, jak i tym, którzy początków konstytucjonalizmu - jeśli nie jako zasady organizacyjnej ustroju państwa, to przynajmniej jako postulatu - doszukują się znacznie wcześniej aniżeli w epoce oświecenia, odrzucając pogląd, wedle którego normy wiążące wolę rządzących i określające reguły sprawowania władzy muszą być zawarte $\mathrm{w}$ spisanym dokumencie.

${ }^{41}$ Zob. B. Bailyn, op. cit., s. 177.

42 J. W. Gough, Fundamental Law in English Constitutional History, Oxford 1955, s. 35.

${ }^{43}$ D. Jenkins, Common Law Declarations of Unconstitutionality, „International Journal of Constitutional Law" 7, 2009, nr 2, s. 186.

${ }^{44}$ Ibidem, s. 193.

${ }^{45}$ Zob. A. Pułło, Idea konstytucjonalizmu $w$ systemie zasad prawa konstytucyjnego, „Przegląd Sejmowy" 1996, nr 5, s. 12 i n. oraz cytowana tam literatura. 
Należący do pierwszej grupy Giovanni Sartori zdefiniował konstytucję jako „ramę społeczności politycznej zorganizowanej poprzez $i$ na podstawie prawa w celu powściągnięcia arbitralnej władzy" ${ }^{46}$. W podobnym duchu, współczesny australijski konstytucjonalista Suri Ratnapala ,istotę konstytucji w filozoficznym sensie” określił jako „,ograniczanie władzy i zapobieganie jej arbitralnemu sprawowaniu poprzez zasadę rządów prawa" ${ }^{47}$. Dla badaczy, których można zaliczyć do drugiej grupy, charakterystyczne jest stanowisko Charlesa H. McIlwaina, który za „kluczową własność” konstytucjonalizmu uznał to, że ,jest on prawnym ograniczeniem rządów; jest antytezą rządów arbitralnych; jego przeciwieństwem są rządy despotyczne, rządy woli zamiast rządów prawa”. Chociaż więc powściąganiu władzy $\mathrm{w}$ warunkach demokracji służą również mechanizmy polityczne, to i tak ,,prawdziwy konstytucjonalizm” pozostaje tym, czym był zawsze: „ograniczaniem rządów poprzez prawo” ${ }^{48}$. Podobnie Andrzej Pułło, który łącząc konstytucjonalizm z ograniczaniem arbitralności władzy, trafnie wskazuje, że ,termin »rządy konstytucyjne« wcale nie oznacza ustroju opartego na konstytucji pisanej”, równocześnie jednak określa go jako ,jedną z idei ogólnych prawa konstytucyjnego", która ma być realizowana przez ,znaczną ilość reguł i zasad [tego] prawa" ${ }^{49}$. Z kolei zdaniem Bogdana Szlachty - podobnie jak Charles H. McIlwain datującego początki konstytucjonalizmu na czasy przed pojawieniem się spisanych konstytucji - „konstytucjonalizm należy kojarzyć $\mathrm{z}$ dążeniem do poddania woli prawodawców i piastunów organów stosujących normy stałemu, »wyższemu «i niezmiennemu prawu o walorze materialnym (naturalnemu, fundamentalnemu lub zwyczajowemu), a niekiedy także proceduralnym (określającym np. sposoby stanowienia prawa lub przekazywania władzy)" ${ }^{50}$.

Zasadniczy postulat konstytucjonalizmu został jednak zrealizowany w Wielkiej Brytanii nie w drodze uchwalenie konstytucji jako najwyższego aktu prawnego, lecz poprzez stopniowe kształtowanie się w ustroju brytyjskim nieformalnych, pozaprawnych norm konstytucyjnych. Eliminacja arbitralności władzy okazała się możliwa bez konieczności odwoływania się do norm prawnych. Źródłami brytyjskiej nieskodyfikowanej konstytucji są oczywiście również normy prawne: prawa stanowionego (statute law), powszechnego (common law) oraz precedensowego (case law). Ze względu na to, że nie maja one wyższej mocy prawnej, nie moga realizować owego postulatu konstytucjonalizmu, którym jest eliminacja arbitralności władzy państwowej. Pojęcie konstytucji materialnej kojarzyć więc należy z zespołem norm odpowiedzialnych za regulację zagadnień ustroju państwa. Posługując się tym pojęciem, należy mieć jednak świadomość, że jedynie część z tych norm ma charakter podstawowych norm wyższego rzędu.

${ }^{46}$ G. Sartori, Constitutionalism: A Preliminary Discussion, „American Political Science Review” 56, 1962, nr 4, s. 860.

${ }^{47}$ S. Ratnapala, op. cit., s. 6.

${ }^{48}$ Ch. H. McIlwain, Constitutionalism: Ancient and Modern, Indianapolis 2010, s. 21.

49 A. Pułło, op. cit., s. 18 i 19.

${ }^{50}$ B. Szlachta, Konstytucjonalizm czy absolutyzm? Szkice z francuskiej myśli politycznej XVI wieku, Kraków 2005, s. 10. 
W amerykańskich koloniach pod koniec XVIII w. narodziła się normatywna koncepcja konstytucji. W XIX w. również Wielka Brytania doczekała się normatywnej konstytucji, ale normy wyższego rządu wyznaczające granice właściwego (konstytucyjnego) postępowania władzy państwowej - wykluczające jej woluntaryzm - nie przybrały tam postaci norm prawnych. Pojęcie „niekonstytucyjności” kojarzone jest w Wielkiej Brytanii najczęściej z naruszeniem normy konwenansowej, nie zaś ze złamaniem prawa ${ }^{51}$.

Wielka Brytania ma oczywiście konstytucję, zestaw norm określających stosunki władcze $\mathrm{w}$ państwie jest bowiem jego koniecznym atrybutem ${ }^{52}$. Brytyjska konstytucja jest jednak specyficzna nie tylko ze względu na to, że nie jest skodyfikowana, ale przede wszystkim dlatego, że jednym z jej źródeł są konwenanse konstytucyjne będące normami o charakterze pozaprawnym, wyposażonymi w sankcję polityczną.

Polityczna konstytucja nie jest więc wyłącznie teoretycznym konceptem forsowanym przez część dwudziestowiecznych brytyjskich konstytucjonalistów, którzy poszukuja skutecznych mechanizmów ograniczania władzy raczej w demokratycznym procesie politycznym aniżeli we władzy sądowniczej ${ }^{53}$. Nie ma ona też waloru wyłącznie deskryptywnego, jak zdają się sugerować niektórzy jej protagoniści ${ }^{54}$. Polityczna konstytucja narodziła się $\mathrm{w}$ rezultacie ewolucji brytyjskiego ustroju w XIX w. Ewolucja ta doprowadziła do ukształtowania norm konstytucyjnych o charakterze pozaprawnym, nazywanych początkowo „zasadami” i „maksymami”, a w końcu konwenansami konstytucyjnymi. Mimo poszukiwania prawnych ograniczeń władzy, brytyjska konstytucja jest nadal konstytucją konwenansową. Normy, dzięki którym eliminowana jest arbitralność władzy, nie mają bowiem charakteru norm prawnych. W ten sposób w Wielkiej Brytanii, podobnie zreszta jak w innych państwach o ustroju westminsterskim, także tych, w których obowiązują konstytucje formalne, nauka o ustroju państwa (w tym zakresie, w jakim dotyczy ona jego zasadniczej części, to jest rozpoznawania i opisu relacji pomiędzy władzą ustawodawczą a wykonawczą) jest ,wyłącznie nauką o polityce" ${ }^{55}$.

dr Tomasz Wieciech

Uniwersytet Jagiellonski w Krakowie

51 V. Bogdanor, S. Vogenauer, Enacting British Constitution: Some Problems, „Public Law” 2008, Spring, s. 45.

${ }^{52}$ Por. V. Bogdanor, The New British Constitution, Oxford-Portland 2009, s. 9.

${ }^{53}$ Tego rodzaju pogląd prezentują G. Gee i G. C. N. Webber, w ogóle nie odnosząc się do historii konstytucyjnej Wielkiej Brytanii. Zob. G. Gee, G. C. N. Webber, What is a Political Constitution?, „Oxford Journal of Legal Studies" 30, 2010, nr 2, s. 281-286.

${ }^{54}$ Zob. J. A. G. Griffith, The Political Constitution, „Modern Law Review” 42, 1979, nr 9.

${ }^{55}$ Por. D. E. Smith, The Crown, Bagehot and the Canadian Constitution, „Canadian Journal of Political Science" 28, 1995, nr 4, s. 623. 


\section{THE PRESCRIPTIVE UNDERSTANDING OF THE BRITISH CONSTITUTION}

\section{Summary}

The word 'constitution' had only a descriptive meaning in the United Kingdom, being synonymous with the frame of government in existence before the American revolutionaries changed its sense by identifying it with the supreme law of the land. The United Kingdom does not, and indeed has never had, a constitution. And yet, it does have one, as its government operates under supreme general rules. Those rules are constitutional conventions. The word 'constitution' started to change its meaning in the United Kingdom when constitutional conventions emerged as rules that constrained, first, the monarch and then the parliament, in the exercising of their legal powers. In the 18th century the constitution was synonymous with law and unconstitutional behaviour was illegal. This changed in the first half of the 19th century when the British constitution became conventional. What it actually meant in the new environment was that to act in an unconstitutional way meant to act against the established convention, even if a given action was perfectly legal. Nevertheless, the British constitution is predominantly political because the supreme constitutional rules are non-legal and are not enforceable in the courts of law. 